DOI: 10.20472/IAC.2019.052.051

\author{
DAVID PROCHÁZKA \\ University of Economics, Prague, Czech Republic \\ TOMÁŠ ZOUHAR \\ University of Economics, Prague, Czech Republic
}

\title{
THE DETERMINANTS OF DISCLOSURES ABOUT INTANGIBLE ASSETS BY LISTED CZECH COMPANIES
}

\begin{abstract}
:
Intangible assets are the main drivers of value creation and the competitive advantage of many firms across all industries. Despite the importance of intangibles in economy increases, their recognition in corporate balance sheets is restricted. Conventional accounting struggles with reliability of their measurement as well as with the uncertainty of their future economic benefits, despite the intangibles reporting provides the users with value-relevant information. The paper tests empirically the level of compliance of listed Czech companies with the disclosure requirements of IAS 38 Intangible assets in their annual reports. Using dataset of financial and non-financial firms from the period 2008-2017 (in total 210 annual reports and 2,730 individual disclosures manually collected), we document a moderate increase in disclosure quality of the sample firms over the period. Consistently with recent research, the evidence of improvement can be attributed to reporting incentives of the firms, acknowledging the importance of capital market to raise capital and, thus, to deliver useful information to the users of financial statements. However, the analysis reveal heterogeneity in the level of compliance across the firms, depending on company's auditor and their ownership structure. Other investigated determinants, such as industry and country origin of the issuer, are not found as relevant.
\end{abstract}

\section{Keywords:}

intangible assets; IAS 38; disclosure quality; listed Czech firms

JEL Classification: M41 